\title{
Correction to: Metapopulation genetics of endangered reticulated flatwoods salamanders (Ambystoma bishopi) in a dynamic and fragmented landscape
}

\author{
Alexander Wendt ${ }^{1}$ D $\cdot$ Carola A. Haas $^{2} \cdot$ Thomas Gorman $^{2,3}$. James H. Roberts ${ }^{1}$
}

Published online: 15 May 2021

(c) Springer Nature B.V. 2021

\section{Correction to: Conservation Genetics \\ https://doi.org/10.1007/s10592-021-01360-3}

Unfortunately, the original publication of the article has been published with an error in the first and fourth author's affiliation. The correct affiliation is given in this correction.

Publisher's Note Springer Nature remains neutral with regard to jurisdictional claims in published maps and institutional affiliations.

The original article can be found online at https://doi.org/10.1007/ s10592-021-01360-3.

Alexander Wendt aswendt91@gmail.com

1 Department of Biology, Georgia Southern University, Statesboro, GA 30460, USA

2 Department of Fish and Wildlife Conservation, Virginia Tech, Blacksburg, VA 24061, USA

3 Aquatic Resources Division, Washington State Department of Natural Resources, Chehalis, WA 98504, USA 